\title{
節理分布性状の確率統計学的モデル化に関する研究（その 1）
}

一対象領域の区分と節理母集団の節理群への区分—

\author{
菊地宏吉*・水戸義忠 ${ }^{*} \cdot$ 本多 畺 $* *$
}

\author{
Stochastic Modelling of Rock Joint Distribution \\ Part 1 : The Devision of the Objective Area into the Modelling Areas \\ and the Division of a Joint System into Joint Sets \\ Kokichi KIKUCHI*, Yoshitada MITO* and Makoto HONDA**
}

\begin{abstract}
Key words : 節理分布 joint distribution, 節理調査 joint survey, 節理群 joint sets, 確率モデル stochastic model
\end{abstract}

\begin{abstract}
Generally, even if joint distribution has a regularity, the regularity is not uniform from the view of wide area. In order to generate the rock joint disutribution-model, therefore, it is necessary to classify previously the survey area into regions for which statistical properties of distribution characteristics are similar as much as possible. The authors suggest such area-division method in this paper

Furthermore, a joint system is composed of several joint sets, and each joint set has its own distributional character. In this paper the authors also suggest the division method of joint system into several joint sets.
\end{abstract}

\section{1. 緒 言}

地下空間の利用が急速に増加し，また，その利用形態 の多様化が進む今日，これら土木構造物の基礎となる岩 盤の力学的 ·水理学的挙動もその目的に対し多様化しつ つある䞮勢である。このような土木構造物の基礎となる 塊状硬質岩盤は, 岩石自体の強度が非常に大きく透水性 も非常に低いために，その工学的性状は不連続面の物理 的性質に強く支配される。このため岩盤の工学的性状を 把握するためには，不連続面系の地質量を適切な形で反 映したモデルを作成し，解析することが必要となる。本 論文では，このように岩盤内に存在する地質学的不連続 面のうち，特に支配的に分布して塊状硬質岩盤の工学的 性状に強い影響を与えると考えられる「節理」に着目し

* 京都大学工学部 Faculty of Engineering, Kyoto Univ.

**清水建設侏)大崎研究室 Ohsaki Reserch Institute, Shimizu Co.
て論を進める。

節理分布のモデル化に関する研究は，これまで節理分 布を特徵づけるいくつかの特性要素に着目して広く行わ れてきたが，これらをまとめたシステムの開発について はほとんど行われていないのが現状である。一般に節理 は規則的な分布性状を示すが，この性質を利用すること によって節理性岩盤における節理分布の確率的なモデル 作成手法を提案することが本論の内容であり，「節理分 布性状の確率統計学的モデル化に関する研究」と題して 3 編に分けて論じることにしたい。

節理分布をモデル化するに当っては，節理の分布に関 する情報を標本調査し，確率統計学的に分布を評価する 必要がある。このような確率論的アプローチを有効に行 うことを目的として，本論文（その1）では，調査によ り得られた標本節理データを，モデル化を行うための統 計的に類似したいくつかの標本集団に区分する手法につ いて提案する。 
一般に，広範な地域に設置される土木構造物基礎の解 析領域の岩盤には, 数系統の節理系（節理の母集団）が 各所に分布し，それぞれが異なった分布性状を呈してい る。このような節理分布の位置的な変化を考慮しなけれ ば，実岩盤の節理分布を十分反映したモデルを作成する ことは不可能となる。したがって，事前に調査領域を節 理の分布性状が同一であるとみなせる領域（統計的に類 似した節理系が分布する領域）に区分し，その各領域に ついてモデルを考えることが必要である。

また，各領域における節理系は，形成時の応力環境に 支配されてほぼ同一の方向性を持って分布する節理群が いくつか組み合わさることによって構成されている。節 理分布を規定する特性要素の分布性状は，この節理群毎 に異なるのが一般的であり（本論文一その 2 -参照), 節理系の分布の評価に扔いては，節理系をいくつかの節 理群に区分し，その節理群毎に分布性状を評価すること が必要となる。

以上を考慮し, 本論文ではすず，2つの代表的な節理 標本調查の手法について述べ，次にこれら各調查手法に より得られるデータの偏り（偏向）について確率統計学 的な視点から考察する。そして, 節理の幾何学的分布性 状を支配する節理特性要素の中で方向性について着目 し，広範な領域を節理分布性状が類似したいくつかの領 域（モデル化領域）に区分する手法について提案する。 さらに，節理系をおおむね同じ方向性を示す節理群に区 分する手法についても提案する。

\section{2. 節理分布の調查手法}

節理が岩盤内に多数存在することは一般によく知られ ている。例えば，KIKUCHI ら ${ }^{1)}$ は花崗岩の良好な平面 露頭 $\left(108 \mathrm{~m}^{2}\right)$ で $30 \mathrm{~cm}$ 以上の節理トレースを1097個 $\left(10.2\right.$ 個 $\left./ \mathrm{m}^{2}\right)$ 記載しているが，普通，解析の対象とな る領域はこの平面露頭の寸法よりもかなり大きく，この 実測データはすべての節理を調査するためには多大な労 力を要することを示唆している。一方，節理を調査する 際には，調査可能な領域は限定されるのが普通であり， すべての節理を調查することは物理的に不可能である。 これらのことを考慮すると，節理の調查は基本的に標本 調查の形を取らざるをえない。

標本調查によって得られる標本集団は標本抽出の際の 偏りのために真の母集団とは一般に異なるため，標本集 団の偏り（偏向）の定式化が可能な調查手法を用いるこ とが必要である。このような標本調査手法としては,

1)調査線を用いる調査, 2) 調査平面を用いる調査の 2 種が考えられる。以下，これらの調査手法について述べ
る。

\section{1 調査線を用いた節理調查}

節理の標本調査手法として従来から広く用いられてい るものが，調查線を用いた標本調查手法である（例えば BAECHER ら ${ }^{2)}$ ，PRIEST and HUDSON ${ }^{3)}$ )。これは岩 盤に有限長の調査線（scanline）を設定し，それと交差 する節理についてのみ記載する方法であり，a)露頭ある いは掘削面等の岩盤表面に調査線を設定するものと, b)ボーリング孔を調査線とみなし，ボアホールテレビ ジョン観察またはコア観察によって調査するものの 2 つに分類することができる。

調査の際に，調査線と交差するすべての節理を対象と するのは必ずしも効率的ではない。多くの過去の研究4) から節理トレース長は負の指数分布型に近似した分布型 を呈しているとされており，工学的に重要でない小規模 な節理ほど多く存在する。このような微寸法の節理を対 象にすることは, 調查量の増大を招き，工学上望むしく ない。このことを考慮し, 岩盤表面に調査線を設定する 調查の場合には，節理を標本とみなす最小のトレース長 を設定する必要がある。

一方，ボーリング孔を用いた調査の場合にはトレース 長を計測することができないので，トレース長と開ロ幅 が相関関係を有する5)ことを考慮して，節理標本とみな す最小の開口幅を設定する方法が考えられる。この場 合，岩盤表面とボーリング孔との標本集団の整合を図る ために，岩盤表面における調査結果と最小のトレース長 $l_{0}$ を用いて，次のようにボーリング孔における最小の開 口幅 $t_{0}$ を決定することを提案する。

$$
t_{0}=\alpha l_{0}^{\beta}
$$

ただし， $\alpha, \beta$ は最小 2 乗法を用いて決定された開口幅 とトレース長の相関関係を示す回帰定数である。なお, ボアホールテレビション観察で同定可能な最小の節理開 口幅は精度上 $0.1 \mathrm{~mm}$ 程度であり ${ }^{6)}$, この場合, 逆に次 式を用いて $l_{0}$ を設定することを提案する。

$$
l_{0}=\{0.1(\mathrm{~mm}) \alpha\}^{1 / \beta}
$$

\section{2 調查平面を用いた節理調查}

調査線による節理標本調査手法のほかに, 従来から提 案されている方法が調查平面を用いた手法である（例え ば，菊地ら ${ }^{7)}$, KULATILAKE and WU') $)$ 。これは露 頭あるいは掘削面等の岩盤表面に調查平面を設定し，そ れと交差する節理について記載する方法である。

平面の形状は調查の簡便性を考慮して単純な幾何を呈 するものが望むしいと考えられる。具体的な形状として は, 円・正方形・長方形が挙げられる。このうち, 円は 等方的で理想的な形状である反面, a)現場での設定が困 
難である，b)円周付近で精度が落ちる，c）密に設定す る場合, 間隙が生じる, 等の理由により適用性が低い。 また長方形の場合, サンプリングの方向に異方性が生 じ，調査の無作為性を損失しかねない。これらを考慮す ると，作業上最も有利で，なおかつ条件を大きく損わな い形状である正方形を平面の形状とするのが妥当である と考えられる。

また, 調査線の場合と同様, 調査の際に調査平面と交 差するすべての節理を対象とするのは効率的でなく，こ の場合も節理標本とみなす最小のトレース長を設定する ことが必要であると考えられる。

\section{3. 標本集団の偏向の補正}

現実に分布する節理の母集団（以下「節理母集団」と する) に対し, 調査によって得られた節理集団（「標本 集団」とする）は調査の手法に起因する「偏向（かたよ り)」を持った集団であるため, 統計的に取り扱うには 各調査手法毎にこの偏向を定式化する必要がある。本章 では, この偏向補正について, 調查線による調查の場合 と調査平面による調査の場合の 2 つに分けて論じる。

\section{1 調查線による調查標本の偏向補正}

調査線を用いた調査によって得られた標本集団は, 主 として次の 2 つ偏向を持つと考えられる。

a）方向性に関する偏向

調査線を用いた調査において，調查線と平行に近い節 理ほど抽出し難くなる（図-1a）。一般に，節理面と調 査線のなす角がそれぞれの節理で異なり，抽出する確率 が異なるために, 結果として標本集団に偏向が生じるこ とになる。この偏向については, TERZAGHI ${ }^{9}$,

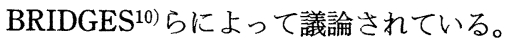

b）連続性に関する偏向

トレース長の大きい節理はトレース長の小さい節理と 比較して抽出しやすい（図-1b）ため，偏向が生じる。 この偏向に関しては BAECHER and LARNEY11)によ って議論されている。

これらの偏向を補正するに当っては，解析の際に各節 理を等価に取り扱うのではなく，それぞれの節理につい て抽出される確率の逆数を用いて, 重み付けすることを 提案する。 2 つ偏向についての重み付けの值（重み係 数）はそれぞれ次のように与えられる。

1）方向性に関する偏向に対する重み係数

同一長さの線分（節理トレース）が調査線と交差する 確率は, 調査線と垂直方向の線分への射影の長さと比例 するため, 重み係数 $W_{O i}$ はその逆数をとって次式で与

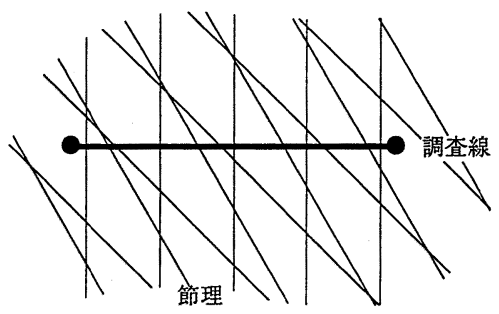

a）方向性による偏向

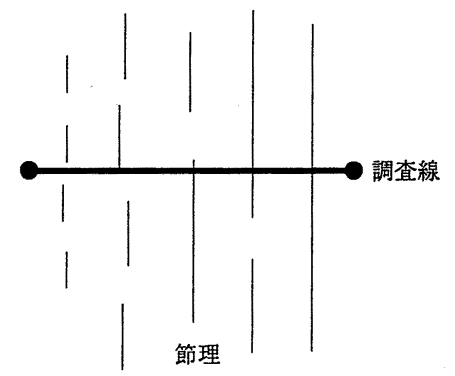

b) 連続性による偏向

図-1 調査手法と標本抽出の偏向

えられる。ここで, $i$ は抽出される節理の番号である。

$$
\begin{aligned}
W_{O i} & =\operatorname{cosec}\left\{\frac{\pi}{2}-\cos ^{-1}\left(\boldsymbol{n}_{i} \cdot \boldsymbol{n}_{L}\right)\right\} \\
& =\frac{1}{\left|\boldsymbol{n}_{i} \cdot \boldsymbol{n}_{L}\right|}
\end{aligned}
$$

ここで, $\boldsymbol{n}_{L}$ は調査線の単位方向ベクトル， $\boldsymbol{n}_{i}$ は節理 面 $i$ 単位法線ベクトルであり,

$$
0 \leq \cos ^{-1}\left(\boldsymbol{n}_{i} \cdot \boldsymbol{n}_{L}\right) \leq \frac{\pi}{2}
$$

とする。

2）連続性に関する偏向に対する重み係数

長さ $L_{L}$, 単位方向ベクトル $\boldsymbol{n}_{L}$ の調査線に対して, ト レース長 $l$ 節理が交差するための必要十分条件は, 節 理トレースの中点が図 $-2 \mathrm{a}$ の点線の範囲内にあること である。この点線内の面積はトレース長 $l$ の関数として 表すことができる。

$$
A(l)=L_{L} l \sin \left\{\cos ^{-1}\left(\boldsymbol{n}_{T} \cdot \boldsymbol{n}_{L}\right)\right\}
$$

ここで $\boldsymbol{n}_{T}$ は節理トレースの単位方向ベクトルである。 この面積が連続性に関する偏向に起因しており，これを 補正するに当っては, 抽出する最小トレース長 $l_{0}$ の節 理がとる中点の範囲の面積を基準とし, その比の逆数を 重み係数とすればよい。したがって，連続性に関する偏 向の重み係数 $W_{L i}$ は次式で与えられる。

$$
W_{L i}=\frac{A\left(l_{0}\right)}{A\left(l_{i}\right)}
$$




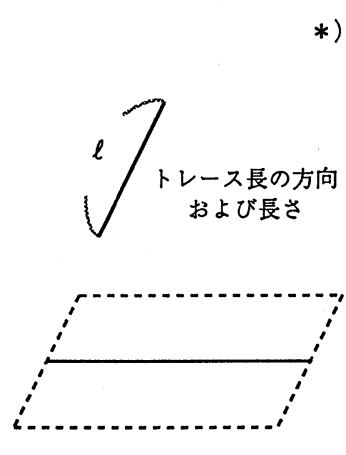

a) 調査線

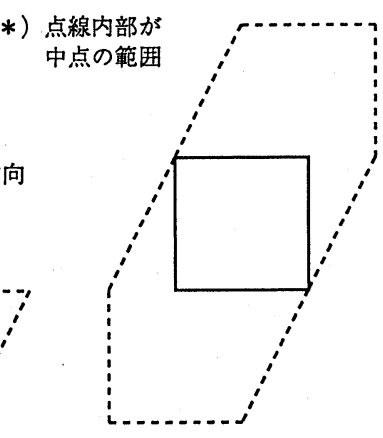

b) 調查平面

図-2 節理トレース中点の存在範囲

$$
\begin{aligned}
& =\frac{L_{L} l_{0} \sin \left\{\cos ^{-1}\left(\boldsymbol{n}_{T} \cdot \boldsymbol{n}_{L}\right)\right\}}{L_{L} l_{i} \sin \left\{\cos ^{-1}\left(\boldsymbol{n}_{T} \cdot \boldsymbol{n}_{L}\right)\right\}} \\
& =\frac{l_{0}}{l_{i}}
\end{aligned}
$$

このように, 調査線による連続性補正式では節理トレ 一ス長と最小トレース長の比の逆数が重み係数となる。

これら 2 つ偏向は互いに独立であるので，2つの偏 向を同時に補正するための重み係数 $W_{i}$ は

$$
W_{i}=W_{O i} \cdot W_{L i}
$$

で与えられる。

\section{2 調査平面による調査標本の偏向補正}

調査平面を用いた調査によって得られた標本集団もま た調査線と同様, 次の 2 つ偏向を有している。

a）方向性に関する偏向

調査平面を用いた調查において，調查平面に平行に近 い節理ほど抽出し難くなる（図-1a)。一般に節理面々 調査平面のなす角がそれぞれの節理で異なり，抽出する 確率が異なるために, 結果として標本集団に偏向が生じ る。

b）連続性に関する偏向

トレース長の大きい節理はトレース長の小さい節理と 比較して標本として抽出しやすい（図一1b）ため, 標 本集団に偏向が生じる。

これらの偏向を補正する際にも調査線の場合と同様, それぞれの節理について抽出される確率の逆数を用いて 重み付けすることを提案する。2つの偏向に関しての重 み係数はそれぞれ次のように与えられる。

1）方向性に関する偏向に対する重み係数

$$
W_{O i}=\frac{1}{\sin \left\{\cos ^{-1}\left(\boldsymbol{n}_{i} \cdot \boldsymbol{n}_{s}\right)\right\}}
$$

ここで $\boldsymbol{n}_{s}$ は調査平面の単位法線ベクトルであり,

$$
0 \leq \cos ^{-1}\left(\boldsymbol{n}_{i} \cdot \boldsymbol{n}_{s}\right) \leq \frac{\pi}{2}
$$

とする。

2）連続性に関する偏向に対する重み係数

調査平面（矩型）の辺長をそれぞれ $L_{W}, L_{N}$ とし，そ の 1 辺の単位方向ベクトルを $\boldsymbol{n}_{n}$ とすると, トレース長 $l$ の節理が交差するための必要十分条件は, 節理トレー スの中点が図- $2 \mathrm{~b}$ の点線の範囲内にあることである。 この点線内の面積はトレース長 $l$ 関数として表すこと ができる。

$$
\begin{aligned}
A(l)= & L_{W} L_{N}+l\left[L_{N} \sin \left\{\cos ^{-1}\left(\boldsymbol{n}_{T} \cdot \boldsymbol{n}_{n}\right)\right\}\right] \\
& +L_{W} \cos \left\{\cos ^{-1}\left(\boldsymbol{n}_{T} \cdot \boldsymbol{n}_{n}\right)\right\} \\
= & L_{W} L_{N}+l\left[L_{N} \sin \left\{\cos ^{-1}\left(\boldsymbol{n}_{T} \cdot \boldsymbol{n}_{n}\right)\right\}\right] \\
& +L_{W}\left(\boldsymbol{n}_{T} \cdot \boldsymbol{n}_{n}\right)
\end{aligned}
$$

この面積が連続性に関する偏向に起因しているため, これを補正するに当っては, 調査線の場合と同様, 抽出 する最小トレース長 $l_{0}$ の節理がとる中点の範囲の面積 を基準とし，その比の逆数を重み係数とする。

$$
\begin{aligned}
W_{L i}= & \frac{A\left(l_{0}\right)}{A\left(l_{i}\right)} \\
& \begin{array}{r}
L_{W} L_{N}+l_{0}\left[L_{N} \sin \left\{\cos ^{-1}\left(\boldsymbol{n}_{T} \cdot \boldsymbol{n}_{n}\right)\right\}\right. \\
=\frac{\left.+L_{W}\left(\boldsymbol{n}_{T} \cdot \boldsymbol{n}_{n}\right)\right]}{L_{W} L_{N}+l_{i}\left[L_{N} \sin \left\{\cos ^{-1}\left(\boldsymbol{n}_{T} \cdot \boldsymbol{n}_{n}\right)\right\}\right.} \\
\left.+L_{W}\left(\boldsymbol{n}_{T} \cdot \boldsymbol{n}_{n}\right)\right]
\end{array}
\end{aligned}
$$

調査平面の場合も 2 つ偏向は互いに独立であるの で，2つの偏向を同時に補正するための重み係数 $W_{i}$ は

$$
W_{i}=W_{O i} \cdot W_{L i}
$$

となる。

このように, 調査線・調査平面のいずれの場合にも, 節理標本の偏向の補正には方向性による偏向の重み係数 および連続性による偏向の重み係数を算出する必要があ るため,すべての節理について方向性のデータのほかに 連続性のデータが必要となる。しかしながら，すべての 節理について連続性（トレース長）を調査することは多 大な労力を要するし，また，ボーリング孔では連続性の 調査は不可能である。したがって, 通常は

$$
W_{i}=W_{O i}
$$

と仮定し, 重み係数を算出するのが一般的と思われる。 


\section{4. モデル化領域の区分方法}

確率統計学的に節理分布の把握およびモデル化を行う に当っては，個々の節理の位置や形状を完全に把握する ことより,むしろ全体的な分布の規則性についての認識 が必要である。節理の分布は一般に規則性を有している が，広域的な視点から見るとその規則性は一様なもので はなく，地域によって変化が見られるのが一般である。 広範な領域で節理系モデルを考える場合, このような節 理分布性状の地域差を考慮しないと, 実岩盤の節理分布 を適切に反映したモデルの作成ができなくなる（図一 3)。

したがって，このような節理分布性状の地域的な変化 をモデル化に反映させるためには, あらかじめ対象領域 を節理分布性状が類似した領域（モデル化領域）に区分 し，各々の領域について統計量の推定を実施することが 必要である。

そこで対象領域を細分化し，各々の領域で節理分布性 状を評価し, 各領域間で類似性の比較を行うことによっ て節理分布性状の地域的な変化を把握する方法を提案す る。

\section{1 対象領域の細分化（部分領域の設定）}

まず，解析の対象となる広範な領域をあらかじめ機械 的に有限個の部分領域に分割する。各部分領域に存在す る節理の標本集団を部分集団とし，この領域においては 節理分布性状に変化はなく同質とみなせるものと仮定す る。すなわち, 分布性状の変化を考慮する必要のない領 域を最小の単位とする。具体的には図ー4a のようなモ デル化対象領域において，図ー4bに示すように部分領 域を設定する。

領域の細分化を進めるに従って，領域内の分布性状の 変化は小さくなるが, 全体的な傾向がつかみにくくな る。それに対して部分領域が大きすぎると部分領域内の 分布性状の分散が大きくなり, 領域区分の目的が達成で きなくなる。

したがって, 部分領域の寸法（最小単位の寸法）につ いては, 調査の目的・範囲・精度, あるいは調査可能な 地点の位置など, さまざなな条件を考慮して適切に決定 しなければならないと考えられる。

\section{2 各部分領域毎の節理分布性状の評価}

4.1節で定めた部分領域内において，先に示した調査 手法を用いて標本調查を行う。各部分領域内では一定の 規則性を持つ単一の母集団を仮定しているため, サンプ リング地点は可能なかぎり, 等間隔に設定するのが統計 的に望ましいが，実際には露頭状況を考慮して設定する

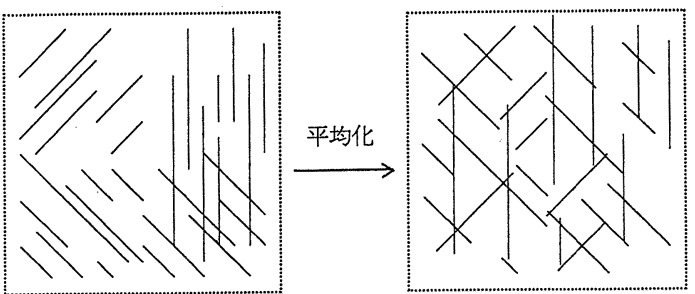

実岩盤

平均化モデル
図-3 モデル化に伴う位置的特質の平均化

ことになる(図-4c)。

節理分布性状を規定する節理特性要素としては，a）方 向性, b) 連続性, c) 稠密性, d) 開口性, e)挟在性, f)粗 面性, g) 連結性等が挙げられ，これらの分布を評価す ることが，当該地域の節相分布性状を評価することにほ かならないが，領域区分を目的とする場合，比較するパ ラメータの分布がその場の節理系を十分に特徴付けるも のでなくてはならない。ここで各節理特性要素の分布 は, いずれも節理系の方向性分布より与えられる節理群 毎に異なった分布を示す（本論文一その 2 -参照）。そ こで対象領域の区分に当っては，その比較パラメータと して方向性分布を評価することにする。図ー4d は各部 分領域で算出した方向性分布に関する統計量をシュミッ ト・ネットに表したもので，黒丸の位置が卓越方向を示 している。

\section{3 類似性の比較基準設定および領域区分}

各部分領域において求められた方向性に関する統計 量，すなわち卓越方向の分布パターンから類似性を検討 することにより，対象領域を分割する。方向性分布がべ クトルで表されることから類似性の度合い（距離測定） としてベクトル間の角度を用いることにする。具体的に 最終的な領域区分の手順は次のとおりである。

各部分領域において得られた卓越する方向べクトルを 合わせて対象領域全体でクラスター分析を行い, クラス ターを形成する。次に，それぞれが属するクラスターの 組み合わせを調べて，その分布パターンを分類する。そ して分布パターンが一致し, かつ隣接する部分領域を連 結して節理母集団（モデル化領域）とする。

ここで卓越方向を求める手法については, 次章で詳し く述べることにして, 対象領域全体についての全卓越方 向ベクトルからクラスターを形成し，クラスターの組み 合わせから分布パターンを分類する際に問題となるの が，クラスターの寸法（卓越方向の範囲を決定する中心 角の大きさ）およびその数をいかにして決定するかであ る。まず, クラスターの寸法については, 小さく設定す 


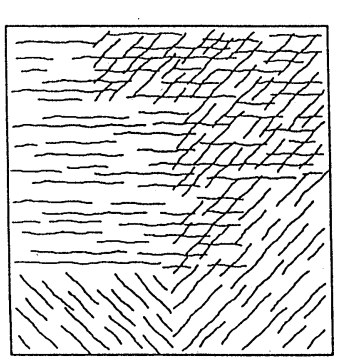

a) モデル化対象領域の設定

ここでは節理の分布性状（節理母集団） が変化するような広域な領域を対象とし ている

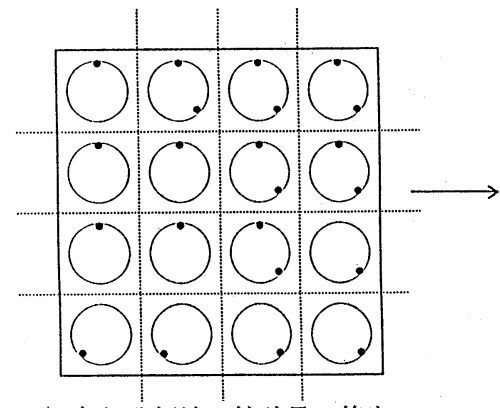

d）各部分領域の統計量の算出

方向性についてシュミットネット上に卓 越方向をけで示している

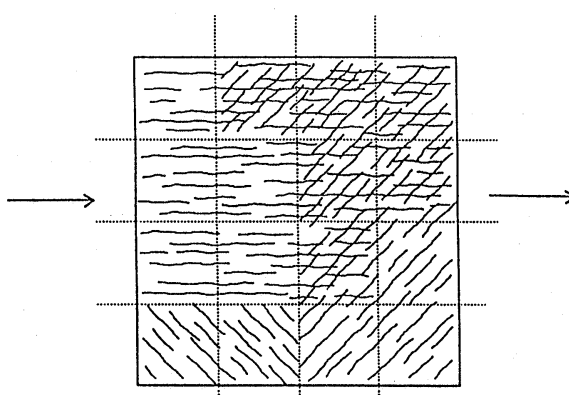

b) 部分領域の設定

対象領域を機械的に分割する

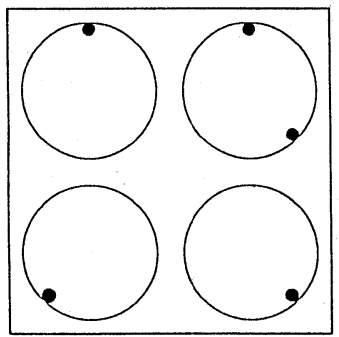

e）類似性判定基準の設定

卓越方向の分布パターンから類似基準を 作成する

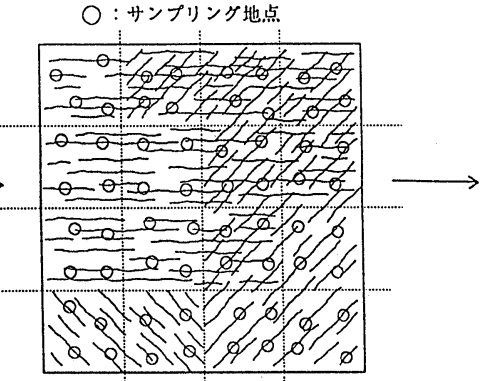

c) 部分領域内の標本調査

各部分領域内の分布性状を把握するため の標本調查を行う地点を配置する

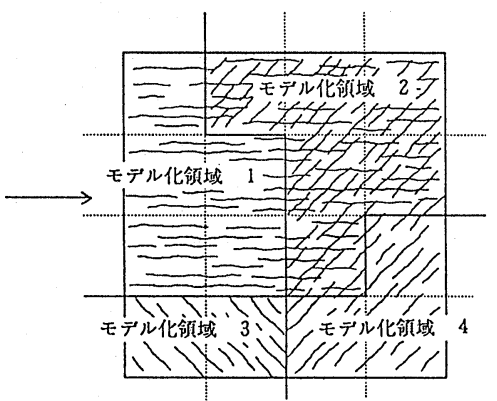

f）モデル化領域の区分

類似性判定基準により領域を区分する

図-4 クラスター分析による領域区分の摸式図

ればそれだけクラスター内での統計的分散が小さくなる が, 逆にクラスターの数を増やさなくてはならず, 組み 合わせの数が増え, 全体的な傾向が把握しにくくなる。 大きく設定すれば組み合わせの数は減るが，逆にクラス ター内での統計的分散が大きくなり，厳密性が薄れる。 したがって, クラスター寸法の設定は, 状況に応じて臨 機応変に決定するのが望ましい。一般的には, クラスタ 一の大きさが全体に占める割合として $10 \%$ 程度を考え た場合，その寸法は中心角で約 $30^{\circ}$ 程度が適当であると 考えられる。

またクラスターの数については, 組み合わせを考慮す る段階で決定することにより，組み合わせの数の増減が 可能である。すなわち, 密度の小さいクラスターなどに ついては，削除するなどして組み合わせ数を減少させる ことが可能である。なお， $m$ 個のクラスターにおける 組み合わせの数 $N_{C}$ は次式によって与えられる。

$$
N_{C}=\sum_{n=1}^{m}{ }_{m} C_{n}+1
$$

ここで, ${ }_{m} C_{n}$ は異なる $n$ 個から $m$ 個取る組み合わせの
数 (Combination) である。

以上の手順でモデル化領域区分が完了する。

\section{5. 節理群の認定}

節理系は一定の応力テンソル場で形成されるため, そ の成因に依存する方向分布形態を呈する場合が多い。各 成因によって生じたこれらの節理は，それぞれ節理群 （おおむね同じ方向性を示す節理集団）をなして分布す る。これらの節理群が集合することによって節理系が形 成される。このように, 節理の方向分布の特徵として節 理群の存在を挙げることとができる。

各節理群は一般に成因が異なるために，その分布性状 も節理群毎に異なることが多い。すなわち節理分布の異 方性を考慮した確率モデルを考える場合, 確率密度関数 におけるパラメトリックな統計的推定を行うために，あ らかじめ節理系をいくつかの節理群に区分しておく必要 がある。

節理系を節理群に区分することは, 基本的には卓越方 向解析と同等であり, 手法としてクラスター分析の密度 
探索法を利用する。

クラスター分析の方法としては, 小さなクラスターを 併合することによりクラスターの寸法を成長させる階層 的方法と, 母集団から始めてクラスターの寸法を個体レ ベルまで減少させる非階層的方法がある12)。ここで用 いる密度探索法は後者の非階層的方法であり, 方向密度 分布より密度の稠密な部分を低密度の部分から分離する ものである。

方向密度分布を把握する手法として，従来からシュミ ット・ネットやウルフ・ネットによる方法が用いられて いるが13)，いずれも 3 次元品間に広がる方向分布を 2 次元平面で表すことによる測定誤差が存在するため，こ

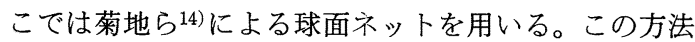
は計算機上で仮想の球面ネットを設定し，球面上で節理 の方向ベクトルの密度を作成するものであり, 特徵とし ては統計処理過程が平面ネットのそれと比較して不偏で あること，および計算機を用いるために簡便であること が挙げられる。具体的には次の手順で行う。

1）密度計测点の設定

密度計測点は, 密度計測の精度の一様性を確保するた めには球面上に等間隔かつ等方に存在しなければならな い。しかしながら，厳密な意味で球面上に等方に点を設 定するのは非常に困難である。そこで球面座標系として 極座標系を用い, 計測点を方位角 $\varphi_{m}$, 天頂角 $\theta_{m}$ が一定 の距離（角度） $\eta$ で配置されることで，均質に近い計測 点の設定を図っている。

$$
\left.\begin{array}{l}
\theta_{m}=i \eta \\
\varphi_{m}=\frac{j \pi \eta}{\pi-|\pi-2 i \eta|}
\end{array}\right\}
$$

ただし，

$$
\begin{aligned}
& i=1,2,3, \cdots, \frac{\pi}{\eta} \\
& j=1,2,3, \cdots, \frac{2(\pi-|\pi-2 i \eta|)}{\eta}-1
\end{aligned}
$$

このほかに

$$
\left.\begin{array}{ll}
\theta_{m}=0, & \pi \\
\varphi_{m}=0
\end{array}\right\}
$$

すなわち, 式(16)の両極点（2 点, 半球では 1 点）を除 けば完全に等方かつ等距離の計測点を設定することがで きる。

2）密度の計測

原点を中心とする球面を考え, 球面上に計測点を中心 とする中心角 $\omega_{m}$ の単位円を描き, その円で聿まれた曲 面内に単位方向ベクトルの終点がある節理について, 式
（7），(12）で定義される重み係数 $W_{i}$ を合計し，これを すべての節理標本の重み係数の合計で除したものを方向 密度 $P_{O}\left(\boldsymbol{n}_{m}\right)$ とする。ここで， $\boldsymbol{n}_{m}$ は単位球面上で原点 を始点, 計測点を終点とする単位べクトルである。この ことを定式化すると次のようになる。

$$
P_{O}\left(n_{m}\right)=\frac{\sum_{i=1}^{N}\left[\frac{W_{i} \max \left\{\omega_{m}-\cos ^{-1}\left(\boldsymbol{n}_{i} \cdot \boldsymbol{n}_{m}\right), 0\right\}}{\omega_{m}-\cos ^{-1}\left(\boldsymbol{n}_{i} \cdot \boldsymbol{n}_{m}\right)}\right]}{\sum_{i=1}^{N} W_{i}}
$$

ここで， $\boldsymbol{n}_{i}$ は各節理面の法線ベクトル， $\boldsymbol{n}_{m}$ は計測点の 方向ベクトル, $\max \{a, b\}$ は $a, b$ の值の大きい方をと る関数である。

単位円の中心角 $\omega_{m}$ の寸法は, 半球面積に対してある 程度小さく設定する必要がある。球の半径が 1 のとき 半球面積が $2 \pi$ であるのに対し, 単位円面積 $S_{m}$ は,

$$
\begin{aligned}
S_{m} & =\int_{0}^{2 \pi \omega} \int_{0}^{m}\left|\frac{\partial r_{m}}{\partial \varphi} \times \frac{\partial r_{m}}{\partial \theta}\right| d \varphi d \theta \\
& =\int_{0}^{2 \pi \omega} \int_{0}^{m} \sin \theta d \varphi d \theta \\
& =2 \pi\left(1-\cos \omega_{m}\right)
\end{aligned}
$$

である。したがって, 半球面積に対する単位円面積の占 める割合 $\gamma_{m}$ は, 次式で示される。

$$
\gamma_{m}=\frac{S_{m}}{2 \pi}=1-\cos \omega_{m}
$$

ここで，例えば $\gamma_{m}=0.01$ とすると中心角は $8.11^{\circ}$ とな る。このように方向密度分布を作成できたら, 次に密度 探索法によるクラスター分析を行い, 節理群の認定を行 う。

3）クラスター分析

密度分布の極大值を探索して, 密度の高い順にその点 を中心とする一定の角度 $\omega_{M}$ を距離測定とするクラスタ 一を形成してこれを分離し，それぞれのクラスターにつ いて節理の集中率（クラスター内に含まれる節理の全体 に対する占有率）を求める。この集中率は次式によって 求められる。ここで, $\omega_{M}$ は最終的に節理群とみなす領 域の距離測度である。

$$
P_{P}\left(n_{P}\right)=\frac{\sum_{i=1}^{N}\left[\frac{W_{i} \max \left\{\omega_{M}-\cos ^{-1}\left(\boldsymbol{n}_{i} \cdot \boldsymbol{n}_{P}\right), 0\right\}}{\omega_{M}-\cos ^{-1}\left(\boldsymbol{n}_{i} \cdot \boldsymbol{n}_{P}\right)}\right]}{\sum_{i=1}^{N} W_{i}}
$$

ここで $\boldsymbol{n}_{P}$ は極大值の単位方向べクトルである。一 方, 節理が等方的に均質に分布している場合, 一定角度 $\omega_{M}$ を距離測度とするクラスター内の密度 $P_{O}$ は式(17) 
より

$$
P_{O}=1-\cos \omega_{M}
$$

である。この $P_{O}$ をもって, クラスターを節理群として 認定する集中率の下限值とする。すなわち， $P_{O}$ 以上の 集中率 $P_{P}\left(\boldsymbol{n}_{P}\right)$ のクラスターを節理群として, それ未満 のクラスターは節理群と認めず有意の差がないものとす る。

以上の手順によってモデル化領域内で計測した節理標 本集団をいくつかの節理群および節理群に属さない節理 集団（非節理群と称する）に区分できることになる。こ のように, 対象とする節理系が方向性に依存するいくつ かの節理群に区分され，これ以降は，この節理群毎に確 率モデルを設定し，関数を規定するパラメータを推定す ることで, 目的とする節理分布のモデル化が可能とな る。

\section{6. 結 語}

節理性岩盤のモデル化を目的として，まず本論文（そ の 1) では, 節理の確率統計学的な調査手法に加えて, 確率分布に基づく統計処理を施すために，調查標本デー タの区分に関する手法を提案した。その内容をまとめる と次の通りである。

1）節理標本集団には調査手法に依存する偏向が存 在する。本論文ではこの偏向を補正するための重み係数 を提案した。この重み係数を用いることにより, 調査線 あるいは調査平面（正方形または矩形）による調査結果 に確率統計学的な処理を行い，母集団統計量を推定する ことが可能となる。

2）対象とする領域が広範な場合, 分布は一様では なく位置的な変化が見られるのが一般である。そこで本 論文では，節理の方向性に着目してクラスター分析を用 いた広域サイトのモデル化領域区分の手法について提案 した。これにより対象領域を統計的に純化されたモデル 化領域に分割することが可能となる。

3）球面ネットを用いた節理群の認定手法を提案し た。この方法は，まず球面ネット上に計測点位置をほぼ 等方かつ等間隔に配置させ，調査手法に依存する偏向を 考慮した密度計測を行い, 得られた密度分布を密度探索 法によりクラスター分析するものである。

以上, 節理分布のモデル化の前段階として節理母集団
の区分の手法について述べた。

\section{参 考 文 献}

1) KIKUCHI, K., MIMURO, T., KOBAYASHI, T., IZUMIYA, Y. and MITO, Y. (1987) A joint survery and determination of joint distribution, 2nd Int. Symp. on Field measurements in Geomechanics, Vol. 1, pp. 239-248.

2) BAECHER, G. B., LARNEY, N. A. and EINSTEIN, H. H. (1977): Statistical description of rock properties and sampling, 18th U. S. Symp. on Rock Mech., pp. 5C1-8.

3) PRIEST, S. D. and HUDSON, J. A. (1981): Estimation discontinuity spacing and trace length using scanline surveys, Int. Jour. Rock Mech. Sci. \& Geomech. Abstr. 13, pp. 135-148.

4) 例えば, KIKUCHI. K., KURODA, H. and MITO, Y. (1987): Stochastic estimation and modelling of jointed rock masses based on staistical sampling, 6th Int. Cong. of ISRM, pp. 425-428.

5）菊地宏吉, 三室俊昭, 大村富士男, 原 敏昭 (1984)：節 理性岩盤のモデル化に関する研究, 第16回岩盤力学に関 するシンポジウム講演論文集, pp. 126-130.

6) 伊藤 一, 小林隆志, 菊地宏吉, 加藤克行, 百田博宣, 伊 藤雅之 (1987)：節理内流れモデルによるルジオン試験結 果の解釈, 第 7 回岩の力学国内シンポジウム講演論文集, pp. 235-240.

7）菊地宏吉, 斉藤和夫, 楠健一郎（1978）：土木構造物基礎 岩盤中の節理分布性状の定量的評価に関する検討, 電力土 木 (発電水力), No. 154, pp. 50-59

8) KULATILAKE, P. H. S. W. and WU, T. H. (1984): Estimation of mean trace length of discontinuities, Rock Mech and Rock Eng. 17, pp. 215-232

9) TERZAGHI, R. (1965): Source of error in Joint surveys, Geotechnique, 15, pp. 287-304.

10) BRIDGES, M. C. (1976): Presentation of fracture data for rock mechanics, 2nd Australian-New Zealand Conderence on Geomechanics, pp. 144-148.

11) BAECHER, G. B. and LARNEY, N. A. (1978): Trase length biases in joint surveys, 19th U. S. symp. on Rock Mech., pp. 56-65

12) EVERITT (1974): Cluster analysis, heinemann Educational books.

13）緒方正虔（1964）：ウルフ網による地質の統計方法の改 良, 応用地質, Vol. 5, No. 25, pp. 81-91.

14）菊地宏吉, 斉藤和雄, 井上大栄, 金折裕司（1976）：岩盤 中の節理分布性状の定量的評価とその解析, 第10回岩盤 力学に関するシンポジウム講演論文集, pp. 1-10

(1992年 3 月 11 日受付, 1992 年 7 月 29 日受理) 